Brabenec, T., Poborsky, F., \& Saßmannshausen, P. (2020). The Difference Between Preferred \& Common Stocks in Europe from the Market Perspective. Journal of Competitiveness, 12(3), 64-81 https:// doi.org/10.7441/joc.2020.02.04

\title{
THE DIFFERENCE BETWEEN PREFERRED \& COMMON STOCKS IN EUROPE FROM THE MARKET PERSPECTIVE
}

\section{- Tomas Brabenec, Frantisek Poborsky, Sean Patrick Saßmannshausen}

\begin{abstract}
Companies listed on the stock market must devote a great deal of attention to their market position. They must increase their competitive advantage in the undeniably key process of the issuance of stocks. As the issuance of preferred stocks has increased after the last crisis and in the current period of low interest rates in Europe, they are becoming more favoured investment instruments, we decided to analyse the real properties of preferred stocks in Europe in order to increase the efficiency of joint-stock companies. Using a dataset comprising all companies having both common and preferred stocks issued and traded on European markets between 20092016, we determined the relationship of risk (measured by beta coefficients) and price volatility among common and preferred stocks and bonds in Europe. Our findings show beta coefficients of preferred stocks as systematically lower than beta coefficients of common stocks. Considering a difference of up to $10 \%$ as negligible, however, preferred stocks showed a similar or higher beta coefficient than corresponding common stocks of the same company in 53\% of cases, whereas for $33 \%$ of cases, the difference is only $\pm 10 \%$. Coefficients of variation in prices showed a similar relationship, with only a negligible portion of preferred stocks bearing fixed (stable) dividends. This result implies that currently traded preferred stocks in Europe in fact do not possess such characteristics they are typically said to have, and in many cases they incur as comparable a risk as do common stocks. This essential information should help to increase the efficiency and competitiveness of joint-stock companies.
\end{abstract}

Keywords: preferred stocks, common stocks, beta coefficient, stock valuation, competitiveness JEL Classification: $G 30$

Received: January, 2020

1st Revision: June, 2020

Accepted: July, 2020

\section{INTRODUCTION}

In this paper, we deal with preferred stocks. According to Hašková et al. (2019), from the corporate finance perspective, preferred stocks are an favoured instrument for some investors, due to their character, i.e. the services that preferred stocks can provide as a special type of equity. For many investors and corporate finance managers, preferred stocks can serve ideally as a source of 
equity with stable dividends with typically a limited impact on company decision-making. Thus, preferred stocks can serve optimally for European companies in which owners leaving executive positions wish to secure their successors, and for European investors who are searching for equity non-minority instruments without participation in the decision-making process (Horák \& Krulický, 2019).

From the valuation perspective, preferred stocks are not a typical asset, so they have to be dealt with carefully. Compared to common stocks, the value of preferred stocks is not entirely in line with the value of the business, so traditional approaches based on company DCF valuation converted to the per share basis do not bring meaningful results (Vrbka \& Rowland, 2017).

The literature generally refers to the special preferential rights of preferred stocks in relation to dividends (fixed dividends / priority over common stocks), their non-voting nature, and nonmanagement control. These are the main reasons preferred stocks are often referred to as "hybrid" financial instruments with a character similar to that of something between common stocks and bonds (for more details see e.g. Wise, 2003; Prohaska et al., 2017; La Porta et al., 2002; Howe \& Lee, 2006 ). This feature of preferred stocks can be advantageous within some of the capital structure theories, where type, character or risks and returns of the capital resources are considered.

Regarding the value of the preferred stocks, it is often emphasized that they have analogical features to bonds (they bear fixed cash-flows) and they are more secure than common stocks (Li et al., 2010). However, if they are convertible, their economic (cash-flow) potential changes (Kallberg et al., 2013; Lewis \& Verwijmeren, 2011) and they must be perceived differently.

For practical use (as a source of corporate finance) and valuation purposes (as a special type of asset), the typical financial character of preferred stocks is debatable. Another consideration is our interest in the European environment because of the development of European financial markets in recent years (Ivanov et al., 2016) and the excess in liquidity (Beaupain \& Durré, 2016) in Europe. This implies that preferred stocks may enjoy the attention of investors and/or companies and thus, it makes sense to analyse the current state of the preferred stock market in Europe.

For investors' decisions as for valuation, a crucial question concerns the risks involved, and in connection the returns associated with preferred stocks. Besides many partial findings related to the special character of preferred stocks, most of the literature refer to preferred stocks as being less risky than common stocks (Loviscek, 2017; Han, 2010). No literature describes empirical research focused on European markets. Moreover, older studies (Han, 2010) are related to outdated periods.

Thus, the aim of this article is to analyse contemporary risk (measured by beta coefficients) and price volatility among common and preferred stocks and bonds in Europe.

\section{THEORETICAL BACKGROUND}

Historically, preferred stocks have been treated and valued incorrectly, even by official organisations such as the U.S. Securities and Exchange Commission. Birger (2008) has discussed how preferred stocks have been dealt with in reorganisations, showing how preferred shareholders 
lost considerable parts of their claims and the values of their investments during reorganisation processes. This was caused by an inaccurate perception of the arrears of preferred dividends and superiority of preferred stocks compared to common stocks in terms of capital claims by the U.S. SEC.

Preferred stocks played a different role in various periods, with their trading having changed in response to changes in the U.S. tax legislation which affected their yields in relation to common stocks in the 1970s. In the 1980s, there was boom in the preferred stocks of utility companies as a consequence of the high demand by insurance companies and other institutional investors (Teplova \& Shabalin, 2017). Concerning more recent periods, the issuance of preferred stocks has been rising since 2009 (Burne, 2013), with preferred stocks becoming a favoured investment vehicle in the current period of low interest rates (Loviscek, 2017). Lewis \& Verwijmeren (2011) add other parameters that make preferred stocks attractive instruments for corporate financing (reduction of income taxes, minimizing refinance costs, mitigation of management discretion costs). Ravid et al. (2007) provide reasoning in the context of whole company performance indicators; the researchers showed how corporate profitability, tax and bankruptcy considerations affect company decision-making to include preferred stocks in the capital sources. Fibírová \& Petera (2013) suggested an appropriate design for profit-sharing plans and the implementation of the participative management style as solutions for worker aversion to invest financial capital in their own firms. It can stated that corporate governance can also affect capital structure and the motives for preferred stock issuance / restraints.

Regarding the performance of preferred stocks, differences have been observed in their yields and the risk involved (Teplova \& Shabalin, 2017; Han, 2010).We consider a market model built by Han (2010) to be effective. The investigator examined the yields of preferred stocks, common stocks and bonds in comparison with various indexes. As the measure of risk, Han (2010) used the beta coefficient, a part of the CAPM (Wang, 2019; Choi \& Choi, 2018; Angeline \& Ariff, 2019; Chang, 2014; Bratton \& Wachter, 2013) and monitored each stock's risk premium in relation to the market. This is consistent with contemporary trends in corporate finance decisionmaking (Brealey et al., 2006) and principles applied in business valuation (Damodaran, 2012) which use beta coefficients as a measurement of systematic risk (a risk for diversified investors).

All companies in Han's (2010) data sample showed lower preferred stock beta coefficients than common stock beta coefficients in relation to the market index. The beta coefficient mean values for common and preferred stocks were nearly 1.0 and 0.2 , respectively. If growing beta coefficients for preferred stocks appeared, according to Han (2010) this is caused by changes in dividend policy. Moreover, preferred stock beta coefficients showed a lower standard deviation. Also, the average coefficient of determination was much lower for preferred stocks, which was according to Han a sign of the preferred stocks' relation to the market index as being much weaker than that of common stocks. He also showed that the link between preferred stocks and bonds was stronger than between common stocks and bonds, but this strength between preferred stocks and bonds was by no means exceptional. (We have examined these claims in our own empirical study, which has brought different conclusions and is referred to below in this 
paper.) Further, according to Teplova \& Shabalin (2017) the factors behind preferred stock yields are: rating; their refundable/non-refundable character; the sinking/non-sinking fund issue; and negotiation with the buyer. If we take into account Abadi \& Florinda (2019) and their conclusions indicating that the optimum for company management is to pay preferred stock dividends as soon as the company has available retained profits, we should expect the performance of preferred stocks (yield, volatility) to be similar to bonds. Moreover, the relationship strength between preferred and common stocks and their price relationship (difference) can vary from country to country (Ferrer et al., 2016; Murayev, 2009; Milonas, 2000).

It has been many times said that usually, investors buy common stocks because they expect a yield as a result of common stock price movements (rise) on the stock market, whereas preferred stocks are purchased on the expectation of receiving stable dividends over a long term. Therefore, investors tend to perceive preferred stocks as an asset with fixed (or well expectable) cash flow, such as fixed-coupon bonds. Meanwhile preferred stocks are usually rated lower (by 1-2 points) compared to bonds (stocks are subordinate to debts) but are said to generate higher yield than bonds issued by the same company (Li et al., 2010; Howe \& Lee, 2006; Wise, 2003).

We are interested in which results provide current data from European markets. To be able to deal with the preferred stocks for practical applications in Europe, we should know what the current relationship and current risk perception from the investors into the preferred stocks is compared to common stocks in Europe. That is why we focused on the relationship between risk of common stocks, preferred stocks and bonds and on the dividend payment patterns related to the preferred stocks.

\section{RESEARCH OBJECTIVE, METHODOLOGY AND DATA MODEL}

Based on relevant literature review conclusions, we can make several expectations that are worth testing:

- Preferred stocks are said to be fundamentally different from common stocks, they have been said to be less risky. Thus, we will analyse the relationship between risks of preferred stocks and common stocks using beta coefficient (see model below) and we will test if beta coefficient of common stocks is always higher than beta coefficient of preferred stocks of the same company (as observed by Han, 2010).

- Preferred stocks are said to pay regular (fixed) dividends, and so their nature is perceived closer to bonds than to common stocks. Thus, we will analyse the development of the preferred stocks' dividends and their regularity.

- Higher risk is connected with higher volatility. We expect that volatility by type of asset is not equal. The literature indicates that there are substantial differences between preferred stocks, common stocks and bonds volatility. We will analyse whether this is true in contemporary conditions.

As the literature suggested that preferred stocks were comparable to common stocks and bonds in several properties, we will deal with the data on prices and trading in common stocks, pre- 
ferred stocks and bonds (if issued) of the companies selected using the specified key. The following data on each security will be used for our empirical research: prices (of common stocks, preferred stocks and bonds), traded volume (of common stocks, preferred stocks and bonds) and dividends (from common stocks and preferred stocks).

First, we will use the up-to-date data from financial markets in Europe to calculate beta coefficients of preferred and common stocks:

$\beta_{j}=\left(\operatorname{COV}\left(\mathrm{R}_{j}, \mathrm{R}_{m}\right)\right) /\left(\operatorname{VAR}\left(\mathrm{R}_{m}\right)\right)$

where $\beta_{j}$ is beta coefficient of stock $j, R_{j}$ is stock yield and $R_{m}$ is market yield.

As for the market benchmark, we use the main indices of the stock exchanges in home countries of the issuers of the securities analysed. We will test whether beta coefficients of preferred stocks are lower than beta coefficients of common stocks, which should mean preferred stocks are less risky than common stocks. We will also measure how homogenous betas the sample have.

Second, we will verify if it is true that preferred stock prices show lower volatility compared to common stock prices, as traditionally considered (Majluf \& Myers, 1984; Myers, 2001). To measure volatility, we use coefficients of variation, since stock prices (and thus their level) could differ substantially. A higher coefficient of variation means a higher variability of price.

We will calculate coefficient of variation as:

$C V=s / \bar{x}$

where $C V$ is coefficient of variation, $s$ is the sample standard deviation, $\bar{x}$ is the sample mean.

The third part of our work will deal with examining the cross correlation. We use Pearson correlation coefficient to show how similarly the prices of the instruments developed. According to literature, preferred stocks should behave like a debt (bonds) when there are no arrears of dividends (and payments are made smoothly). Thus, we will test whether there is an observable higher correlation coefficient between preferred stocks and bonds than between common stocks and bonds.

We will test the statistically significant difference between means (of beta, coefficient of variation and correlation coefficient) of each type of asset (preferred stocks, common stocks, bonds) using paired samples t-test. In case of differences between calculated characteristics of each type of asset, the p-value should be less than 0.05 ( $95 \%$ confidence interval). Four sets of differences (from nine) meet the assumption of normal distribution on $5 \%$ significance level and six on 1\% significance level. Even though t-test is quite robust, we examined the results with nonparametric Wilcoxon signed-rank test. Wilcoxon signed-rank test proved the same conclusions as our results based on paired samples t-test.

\subsection{Sample data}

The daily data since 2009 until half of the year 2016 were used for the empirical analysis, given the availability of the data until the moment when exported from S\&P Capital IQ and the period covering the developments since the start of the financial crisis in 2008. Data covered information of middle price between bid and ask, volume of trading, date and dividends. 
Standard \& Poor's Capital IQ database was used in selecting the sample. From S\&P Capital IQ, we chose those companies which issued common stocks - as many as 181,165 worldwide. Given the focus of our research, we then limited the sample data to those companies which also issued preferred stocks, which reduced the number of companies to 3,287. The following diagram shows the geographical distributions of the companies having issued just common stocks (diagram on the left) and those having issued both common and preferred stocks (diagram on the right).
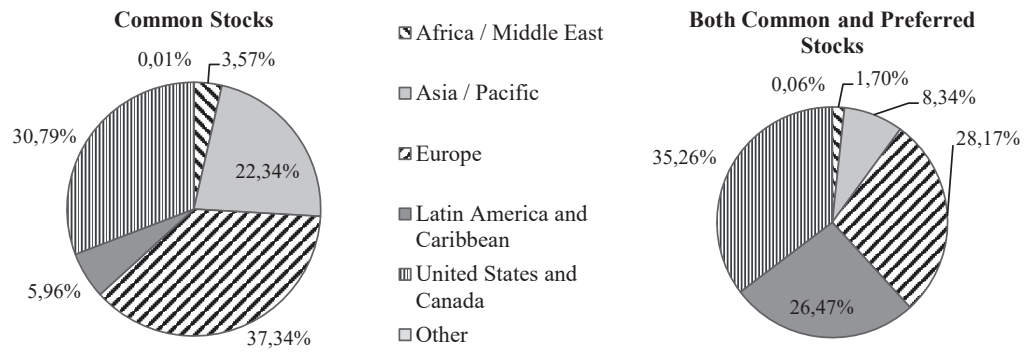

Fig. 1 - Geographical Distribution of Companies by Type of Stocks Issued. Source: S\&P Capital IQ database, presentation of authors

Industries such as financials (40.7\%), consumer discretionary (8.4\%) and industrials (9.5\%) prevail even after taking into account the preferred stocks issued. Finance industry companies show a majority, which is in accordance with Investopedia (2019). Prevailing finance industries are as follows: asset management $(10.0 \%)$, regional banks $(6.2 \%)$, diversified banks $(5.8 \%)$.

Because of the data set size and the differences in capital markets in the USA and Europe, we used only the data for those companies which have issued both common and preferred stocks and are seated in Europe.

The dataset was further reduced to those companies whose stocks are traded on the stock exchange (This condition has its reason because the corporate stocks without price movements would have negative impacts on the conclusions from our analyses). A sample of 158 companies was thus obtained. Further data cutback has been performed because of low trading days/volumes throughout the reporting period. We have removed companies whose stocks did not show an average of 1 trade in 10 working days (minimal one trade in two weeks). This measure reduced the risk of misrepresenting the results of the study due to reporting a share price that would not be based on actual transactions.

The last filtering criterion was based on the minimum days we have data on (preferred stock prices, common stock prices or bonds). Very short-term price data can be expected to be more homogeneous than long-term data. We decided for a period of data longer than 2.5 years in the last five years, because of data requirements for calculations. 
These adjustments led to the final sample of 115 companies in our data set.

Majority of companies with both preferred and common stocks are seated in Russia (37), Germany (16), Italy (13) and Sweden (10), in total 66.1\% from the data set. The sectors with the largest number of companies are financials (29.6\%), industrials (19.1\%), utilities (13.0\%) and materials (10.4\%).

\section{RESULTS AND DISCUSSION}

We calculated the beta coefficients for the preferred stocks and the common stocks included in our sample, and irrespective of what parameters were used for the beta coefficient calculation (5 year and 2 year periods and monthly/weekly yield were considered), the conclusions were almost identical: It is not true anymore that preferred stock beta coefficients are always (or at least in a vast majority of cases) lower that common stock beta coefficients (as opposed to Han (2010)). Our results are based on a 5-year period, weekly yield (for beta) and daily prices (for variability and correlation).

The sample we analysed including a large number of companies whose preferred and common stocks showed approximately the same beta coefficients - there were as many as $1 / 3$ of such companies in the sample. Moreover, a large number of companies' preferred stocks showed a higher beta coefficient (and thus a higher yield) than their common stocks - the share of such companies accounted also for about $1 / 3$. On the contrary, there were $20 \%$ of the cases with the preferred stock beta coefficient being significantly lower than the common stock beta coefficient (quintuples were observed).

The following diagram shows the ratio of preferred stock beta coefficients and common stock beta coefficients for 5 -year beta coefficients calculated using weekly yields (Alternative calculations with other periods and other reference frame provide similar conclusions, they are not presented here to facilitate clarity).

This leads to a conclusion: the beta as for a company's preferred stocks is not always lower than beta as for its common stocks. Even though, most companies in our sample showed lower beta coefficients for their preferred stocks (as much as 61\% of cases), many companies with the preferred stocks, which had beta almost identical to that of their common stock, exist. Moreover, there exist $39 \%$ of cases where preferred stock beta is higher than common stock beta.

Consequently, this allows no general conclusion that any of the groups we analysed (preferred/ common stocks) should now have, on a regular basis, the beta higher or lower than the other group, which was the case in history, as shown in the studies referred to above. We show the change in relationship between betas of preferred and common stocks in Figure 2. While no company had a higher common stock beta than the preferred stock beta in Han's (2010) research and the betas were not even close to each other, a current relation is significantly different (see Figure 2). 


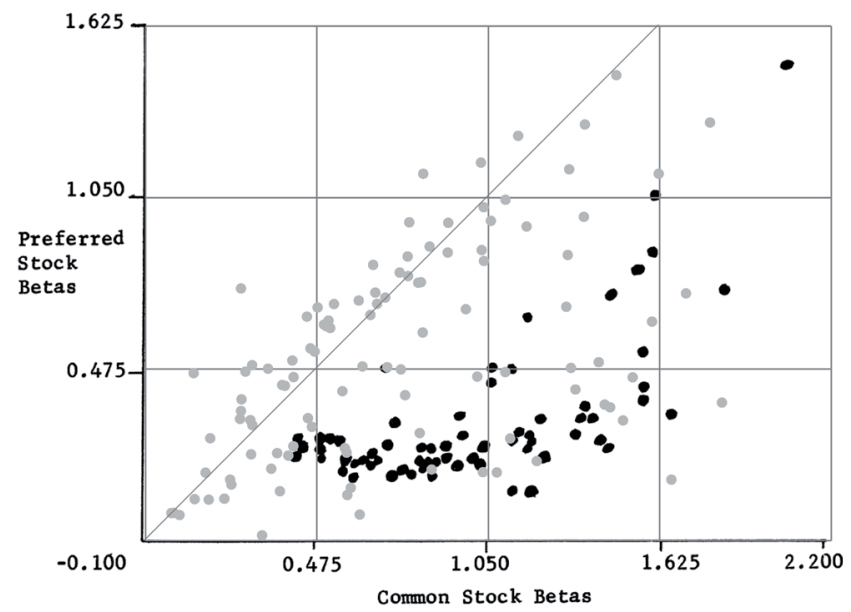

Fig. 2 - Comparison of Han's and contemporary Preferred Stock Beta Coefficients (Vertical Axis) and Common Stock Beta Coefficients (Horizontal Axis). Source: Original Han's (2010) figure (black) and own calculations (grey) based on data from S\&P CAPITAL IQ

Note: Some extreme values are omitted from the diagram, because its boundaries are chosen for the sake of clarity - however, these extremes are just several isolated cases.

As literature often compares the yield (and other factors) of preferred stocks with the bonds, we also compared the betas of preferred stocks and that of bonds issued by the same company. A marked majority of preferred stocks (approximately 69\% in the long term) generate higher betas than bonds and about the same betas are observed in about 35\% of preferred stocks and bonds.

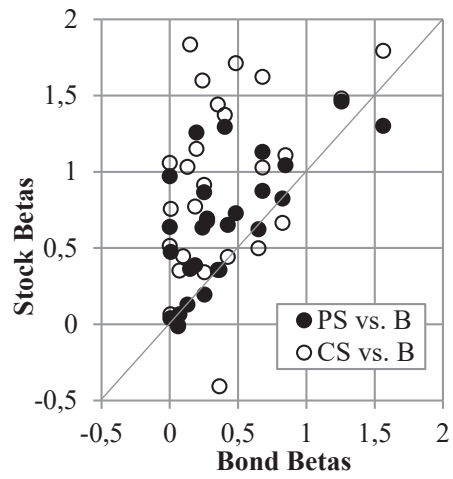

Fig. 3 - Comparison of Preferred Stock. Beta Coefficients (PS) and Common Stock. Beta Coefficients (CS) and Bond Beta Coefficients (B). Source: own calculations based on data from S\&P CAPITAL IQ

Note: Some extreme values are omitted from the diagram because its boundaries are chosen for the sake of clarity - however, these extremes are just several isolated cases. 
Consequently, this allows a conclusion that in most cases, the current betas of preferred stocks are higher than the betas of the bonds issued by the same company. If we accept beta as a crucial variable for required return on asset in CAPM model, we can state that this implies preferred stocks having generally higher yields than bonds.

Our findings support our estimations. The highest beta coefficient can be observed for common stocks (average 0.76), followed by preferred stocks (0.52) and bonds with the lowest beta coefficient $(0.39)$, thus lowest risk. The difference between beta coefficients is statistically significant at the level of $5 \%$ significance (see Table 2).

However, within our data set, about $1 / 3$ of issuers differ - we observed $39 \%$ probability of preferred stocks' beta to be higher than common stocks' beta and $31 \%$ probability of bonds' beta to be higher than preferred stocks' beta. For 15\% of issuers, beta of bonds is higher than beta of preferred stocks and this is higher than common stocks.

Tab. 1 - Descriptive statistics of beta coefficients by type of asset. Source: own calculation based on data from S\&P CAPITAL IQ

\begin{tabular}{|l|l|l|l|}
\hline Description & Preferred Stock & Common Stock & Bond \\
\hline Valid N & 110 & 115 & 27 \\
\hline Mean & 0.52 & 0.76 & 0.39 \\
\hline Minimum & -0.26 & -0.41 & 0.00 \\
\hline Lower Quartile & 0.22 & 0.36 & 0.11 \\
\hline Median & 0.48 & 0.66 & 0.25 \\
\hline Upper Quartile & 0.76 & 1.07 & 0.56 \\
\hline Maximum & 1.65 & 4.44 & 1.56 \\
\hline Range & 1.91 & 4.85 & 1.56 \\
\hline Interquartile Range & 0.54 & 0.71 & 0.45 \\
\hline Standard Deviation & 0.38 & 0.60 & 0.39 \\
\hline Coefficient of Variation & 0.72 & 0.79 & 1.01 \\
\hline
\end{tabular}

Tab. 2 - Difference of beta coefficients by type of asset. Source: own calculation based on data from S\&P CAPITAL IQ

\begin{tabular}{|c|c|c|c|}
\hline \multicolumn{3}{|c|}{ Beta coefficients } \\
\hline & $\begin{array}{l}\text { Preferred Stock higher } \\
\text { than Common Stock }\end{array}$ & $\begin{array}{l}\text { Preferred Stock higher } \\
\text { than Bond }\end{array}$ & $\begin{array}{l}\text { Common Stock higher } \\
\text { than Bond }\end{array}$ \\
\hline Yes & $39 \%$ & $69 \%$ & $85 \%$ \\
\hline No & $61 \%$ & $31 \%$ & $15 \%$ \\
\hline Total & $100 \%$ & $100 \%$ & $100 \%$ \\
\hline \multicolumn{3}{|r|}{ Paired samples t-test } \\
\hline
\end{tabular}




\begin{tabular}{|c|c|c|c|c|c|c|}
\hline Variable 1 & Variable 2 & N & p-value & $\begin{array}{c}\text { Mean Dif- } \\
\text { ference }\end{array}$ & $\begin{array}{c}95 \% \text { Confidence Interval } \\
\text { of the Difference }\end{array}$ \\
\cline { 5 - 7 } & & & Lower & Upper \\
\hline $\begin{array}{c}\text { Preferred } \\
\text { Stock }\end{array}$ & $\begin{array}{c}\text { Common } \\
\text { Stock }\end{array}$ & 110 & 0.0000 & -0.236 & -0.335 & -0.137 \\
\hline $\begin{array}{c}\text { Preferred } \\
\text { Stock }\end{array}$ & Bond & 26 & 0.0005 & 0.270 & 0.132 & 0.408 \\
\hline $\begin{array}{c}\text { Common } \\
\text { Stock }\end{array}$ & Bond & 27 & 0.0001 & 0.512 & 0.304 & 0.721 \\
\hline
\end{tabular}

In our preferred stock analysis, we also dealt with dividend payments. In essence, literature is in unanimous agreement in that preferred stock typically bears fixed dividend. However, this widely accepted thesis has not been proved right on the sample we analysed: After 2009, as little as $63-73 \%$ of preferred stocks paid at least some dividend within particular years observed. For the whole period, as much as $20 \%$ of preferred stocks bore no dividend. In the same period, as much as $55-63 \%$ of common stocks paid at least some dividend, and for the whole period, no dividend was paid on as much as $26 \%$ of common stocks. Even though preferred stocks bore dividend in more cases than common stocks, that cannot be regarded as a rule. Moreover, we identified only $20 \%$ of cases in which the dividend paid on preferred stocks can be treated as stable or regularly growing. No dividend or decreasing dividend was in $20 \%$ of cases.

Therefore, our analysis leads to a conclusion that at present, preferred stocks in Europe typically do not bear fixed dividends, which is highly inconsistent with their general perception. The preferred stocks in Europe bear mostly no dividend or unfixed dividend. Between $13-45 \%$ of the companies paid fixed dividends between two subsequent years and no company paid fixed dividends in the whole period 2010-2015 (only one in the period 2011-2015).

The beta coefficients calculated from historical yields also reflect the regular risks associated with individual titles for which investors (investing in preferred or common stocks) require remuneration.

Moreover, we also examined stock price volatility, by which we monitor the risk for the investor that the stock price will change, which changes are not a base for beta coefficient. Since stock prices are not always the same, we analysed and compared their coefficients of variation. In $44 \%$ of cases, preferred stock prices showed a higher coefficient of variation than common stock prices and a higher coefficient of variation in common stock prices accounted for $56 \%$. The coefficients of variation in preferred stock prices and common stock prices were rather close to each other in $61 \%$ of cases (The difference of coefficients of variation is in interval from - 0.1 to 0.1 ).

Even though the sample we analysed included companies with preferred stocks showing a significantly lower coefficient of variation of prices (mean 0.30) than their common stocks (mean 0.37). The lowest coefficient of variation showed bonds (mean 0.21). Based on paired sample t-test, the mean between common stocks' and preferred stocks' price volatility is not similar on the significant level of 0.05 (see Table 4), which means we can expect higher volatility of common stocks than preferred stocks - the mean difference of coefficient of variation is 0.07 . 
Tab. 3 - Descriptive statistics of coefficients of variation by type of asset. Source: own calculation based on data from S\&P CAPITAL IQ

\begin{tabular}{|l|l|l|l|}
\hline Description & Preferred Stock & Common Stock & Bond \\
\hline Valid N & 110 & 115 & 27 \\
\hline Mean & 0.30 & 0.37 & 0.21 \\
\hline Minimum & 0.02 & 0.02 & 0.00 \\
\hline Lower Quartile & 0.14 & 0.20 & 0.04 \\
\hline Median & 0.23 & 0.28 & 0.17 \\
\hline Upper Quartile & 0.40 & 0.44 & 0.28 \\
\hline Maximum & 1.11 & 1.76 & 0.92 \\
\hline Range & 1.10 & 1.74 & 0.92 \\
\hline Interquartile Range & 0.26 & 0.23 & 0.24 \\
\hline Standard Deviation & 0.21 & 0.27 & 0.20 \\
\hline
\end{tabular}

Tab. 4 - Difference of coefficients of variation by type of asset. Source: own calculation based on data from S\&P CAPITAL IQ

\begin{tabular}{|c|c|c|c|c|c|c|}
\hline \multicolumn{7}{|c|}{ Coefficient of Variation - prices } \\
\hline & \multicolumn{2}{|c|}{$\begin{array}{l}\text { Preferred Stock bigger } \\
\text { than Common Stock }\end{array}$} & \multicolumn{2}{|c|}{$\begin{array}{l}\text { Preferred Stock bigger } \\
\text { than Bond }\end{array}$} & \multicolumn{2}{|c|}{$\begin{array}{l}\text { Common Stock bigger } \\
\text { than Bond }\end{array}$} \\
\hline Yes & \multicolumn{2}{|c|}{$44 \%$} & \multicolumn{2}{|c|}{$62 \%$} & \multicolumn{2}{|c|}{$93 \%$} \\
\hline No & \multicolumn{2}{|l|}{$56 \%$} & \multicolumn{2}{|l|}{$38 \%$} & \multicolumn{2}{|l|}{$7 \%$} \\
\hline Total & \multicolumn{2}{|l|}{$100 \%$} & \multicolumn{2}{|l|}{$100 \%$} & \multicolumn{2}{|l|}{$100 \%$} \\
\hline \multicolumn{7}{|c|}{ Paired samples t-test } \\
\hline \multirow[t]{2}{*}{ Variable 1} & \multirow[t]{2}{*}{ Variable 2} & \multirow[t]{2}{*}{$\mathrm{N}$} & \multirow[t]{2}{*}{$\mathrm{p}$-value } & \multirow[t]{2}{*}{$\begin{array}{l}\text { Mean Dif- } \\
\text { ference }\end{array}$} & \multicolumn{2}{|c|}{$\begin{array}{l}95 \% \text { Confidence Interval } \\
\text { of the Difference }\end{array}$} \\
\hline & & & & & Lower & Upper \\
\hline $\begin{array}{l}\text { Preferred } \\
\text { Stock }\end{array}$ & $\begin{array}{l}\text { Common } \\
\text { Stock }\end{array}$ & 110 & 0.0011 & -0.069 & -0.110 & -0.029 \\
\hline $\begin{array}{l}\text { Preferred } \\
\text { Stock }\end{array}$ & Bond & 26 & 0.0034 & 0.079 & 0.029 & 0.129 \\
\hline $\begin{array}{l}\text { Common } \\
\text { Stock }\end{array}$ & Bond & 27 & 0.0001 & 0.153 & 0.090 & 0.215 \\
\hline
\end{tabular}

Volatility of preferred and common stocks is mostly similar or higher by common stocks. The difference is clearer by bonds - the coefficient of variation is in general lower or the same by bond prices than by stocks. Actually, the coefficient of variation is higher by common stock than by bonds in $93 \%$ cases. The betas and coefficients of variation confirm the expectation that common stocks have the highest risk and volatility and bonds have the lowest. 
The strongest relationship of volatilities (measured by coefficients of variation) is between preferred stocks and bonds (correlation coefficient 0.85), the weakest relationship is between preferred stocks and common stocks (correlation coefficient 0.63 ). The relationship of volatilities between common stocks and bonds has the correlation coefficient 0.79 . This is consistent with the relationship between the correlation coefficient of betas, which is strongest for preferred stocks and bonds and is equal to 0.65 , when the correlation coefficient between betas of preferred stocks and common stocks is 0.48 (similar for the correlation coefficient between betas of common stocks and bonds: 0.43 ).

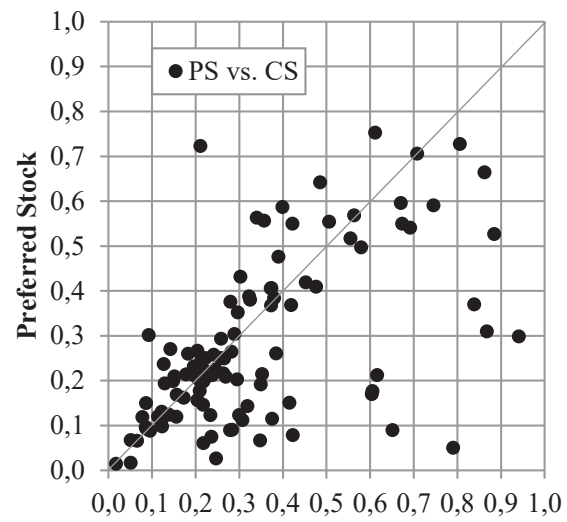

Common Stock

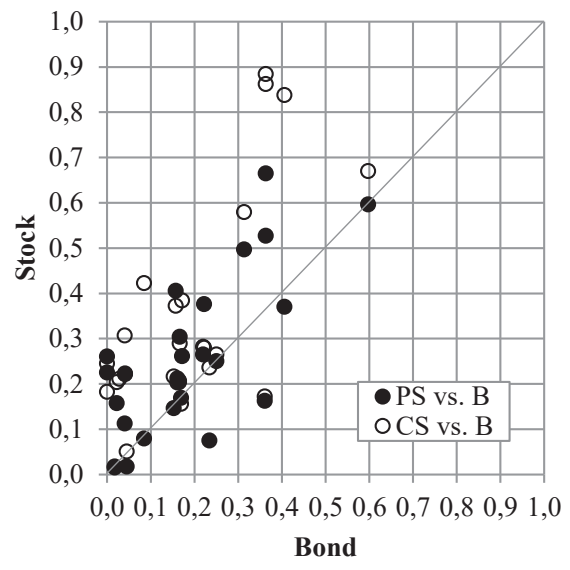

Bond

Fig. 4 - Comparison of Coefficients of Variation in Preferred Stock Prices (Vertical Axis) and Common Stock Prices (Horizontal Axis) and Comparison of Coefficients of Variation in Preferred (PS) and Common (CS) Stock. Prices (Vertical Axis) and Bond (B) Prices (Horizontal Axis). Source: own calculation based on data from S\&P CAPITAL IQ

Finally, we examined the correlation between preferred stock prices and common stock prices, with results showing a strong dependence of preferred stock prices on common stock prices (median of correlation coefficient is 0.84 ). This upholds our previous conclusions that currently preferred stocks in Europe are rather similar to common stocks (in terms of betas (yields) to a reasonable degree). For the vast majority of cases the coefficient of correlation between preferred stock prices and common stock prices is 0.7 or higher ( $65 \%$ of cases; $45 \%$ cases above 0.9 ), which is evidence of a strong dependence.

Preferred stock prices correlate with bond prices relatively strongly; yet the strength of dependence is weaker if all $65 \%$ of observations in preferred and common stocks are considered, whereas "just" $58 \%$ of observations in preferred stocks and bonds fall within the 0.7-1.0 range of coefficient of correlation ( $33 \%$ is above 0.9$)$.

It is interesting that a large number of common stock prices and bond prices show a strong positive correlation $(60 \%$ cases are above 0.7 and $32 \%$ cases above 0.9$)$. This demonstrates that stock prices and bond prices were rising primarily for fundamental reasons related to the issuing 
companies as such - otherwise one interest group would profit from the company at the expense of the other group, which was not the case very often.

The mean values of correlation coefficients can be ranked from the strongest (preferred stocks and common stocks) to the weakest (common stocks and bonds), with the difference between the averages of these coefficients not statistically significant.

Tab. 5 - Descriptive statistics of correlation coefficients by type of asset. Source: own calculation based on data from S\&P CAPITAL IQ

\begin{tabular}{|l|l|l|l|}
\hline Description & $\begin{array}{l}\text { Preferred Stock } \\
\text { vs. Common } \\
\text { Stock }\end{array}$ & $\begin{array}{l}\text { Preferred Stock } \\
\text { vs. Bond }\end{array}$ & $\begin{array}{l}\text { Common Stock } \\
\text { vs. Bond }\end{array}$ \\
\hline Valid N & 110 & 24 & 25 \\
\hline Mean & 0.68 & 0.66 & 0.62 \\
\hline Minimum & -0.69 & -0.47 & -0.68 \\
\hline Lower Quartile & 0.60 & 0.53 & 0.63 \\
\hline Median & 0.84 & 0.81 & 0.73 \\
\hline Upper Quartile & 0.94 & 0.96 & 0.92 \\
\hline Maximum & 1.00 & 1.00 & 0.99 \\
\hline Range & 1.69 & 1.47 & 1.67 \\
\hline Interquartile Range & 0.34 & 0.44 & 0.29 \\
\hline Standard Deviation & 0.39 & 0.40 & 0.44 \\
\hline Coefficient of Variation & 0.57 & 0.61 & 0.71 \\
\hline
\end{tabular}

Tab. 6 - Difference of correlation coefficients by type of asset. Source: own calculation based on data from S\&P CAPITAL IQ

\begin{tabular}{|c|c|c|c|c|c|c|}
\hline \multicolumn{7}{|c|}{ Correlation Coefficient - prices } \\
\hline & \multicolumn{2}{|c|}{$\begin{array}{l}\text { Preferred vs. Common } \\
\text { Stock bigger than Pre- } \\
\text { ferred Stock vs. Bond }\end{array}$} & \multicolumn{2}{|c|}{$\begin{array}{l}\text { Preferred vs. Common } \\
\text { Stock bigger than Com- } \\
\text { mon Stock vs. Bond }\end{array}$} & \multicolumn{2}{|c|}{$\begin{array}{l}\text { Preferred vs. Bond big- } \\
\text { ger than Common Stock } \\
\text { vs. Bond }\end{array}$} \\
\hline Yes & \multicolumn{2}{|c|}{$58 \%$} & \multicolumn{2}{|c|}{$63 \%$} & \multicolumn{2}{|c|}{$67 \%$} \\
\hline No & \multicolumn{2}{|l|}{$42 \%$} & \multicolumn{2}{|l|}{$38 \%$} & \multicolumn{2}{|l|}{$33 \%$} \\
\hline Total & \multicolumn{2}{|l|}{$100 \%$} & \multicolumn{2}{|l|}{$100 \%$} & \multicolumn{2}{|l|}{$100 \%$} \\
\hline \multicolumn{7}{|c|}{ Paired samples t-test } \\
\hline \multirow[t]{2}{*}{ Variable 1} & \multirow[t]{2}{*}{ Variable 2} & \multirow[t]{2}{*}{$\mathrm{N}$} & \multirow[t]{2}{*}{$\mathrm{p}$-value } & \multirow{2}{*}{$\begin{array}{l}\text { Mean Dif- } \\
\text { ference }\end{array}$} & \multicolumn{2}{|c|}{$\begin{array}{l}95 \% \text { Confidence Interval } \\
\text { of the Difference }\end{array}$} \\
\hline & & & & & Lower & Upper \\
\hline $\begin{array}{l}\text { Preferred } \\
\text { Stock vs. } \\
\text { Common } \\
\text { Stock }\end{array}$ & $\begin{array}{l}\text { Preferred } \\
\text { Stock vs. } \\
\text { Bond }\end{array}$ & 24 & 0.6748 & 0.041 & -0.148 & 0.229 \\
\hline
\end{tabular}




\begin{tabular}{|l|l|l|l|l|l|l|}
\hline $\begin{array}{l}\text { Preferred } \\
\text { Stock vs. } \\
\text { Common } \\
\text { Stock }\end{array}$ & $\begin{array}{l}\text { Common } \\
\text { Stock vs. } \\
\text { Bond }\end{array}$ & 24 & 0.3985 & 0.080 & -0.112 & 0.271 \\
\hline $\begin{array}{l}\text { Preferred } \\
\text { Stock vs. } \\
\text { Bond }\end{array}$ & $\begin{array}{l}\text { Common } \\
\text { Stock vs. } \\
\text { Bond }\end{array}$ & 24 & 0.6216 & 0.039 & -0.113 & 0.191 \\
\hline
\end{tabular}

Our analyses show that price development of both bonds and preferred stocks is close to that of common stocks. However, each of these shows a different level of risk. The most sensitive in terms of price fluctuations are stocks, particularly common stocks.

From the capital structure perspective, our findings show that preferred stocks should be generally connected to slightly lower returns than common stocks, and thus they could be used as a cheaper source of (equity) financing. However, our data set (115 pairs) is limited to the extent of companies issuing both traded common and preferred stocks along with a few further criteria (see above for details). We have also seen that this is not true for a substantial portion of the companies. Thus, individual company conditions might play a role (which has not been analysed in this research). Our ambiguous conclusions suggest that investors perceive preferred stocks as less risky than common stocks, but they strongly take into account particular conditions of preferred stocks and incorporate these into their pricing. As a side effect, based on the data sample, we can conclude that preferred stocks were not popular among investors in the observed period (158 traded issues in Europe).

Boudry et al. (2020) published a study focusing on a similar issue. In their research, they are concerned with the advantages of preferred and common stock diversification of the REIT type using a utility-based framework in which investors segment based on risk aversion. The authors examine the ideal investor portfolio with a different degree of risk aversion while taking the specific approach to various categories of assets into account. Based on this foundation, they establish the three main results. Firstly, the REIT common stocks help the investors with a low risk aversion to build portfolios with higher revenues, while the REIT preferred stocks help the investors with a high-risk aversion by providing the opportunity to decrease risk. Secondly, the REIT preferred stocks have a profile of revenue risk that is not easily replicable by other categories of assets. Under these restrictions, the conclusion drawn from the empirical analysis differs significantly from the classic unlimited conception. Milonas (2000) concentrated on a further examination of price differences (price range) between the common and preferred stock in the time period from 1990 to 1995 based on a sample of 55 businesses in Greece. As the preferred stocks in Greece are basically similar to the common stocks (except for the privilege of voting on company management issues which belong exclusively to common stockholders), the author tested multiple hypotheses to examine the observed differences. In cross-sectional regressions, it was found that the volatility of common stock returns, the liquidity of common shares relative to preferred shares, ownership concentration, and the minimum dividend yield guaranteed to preferred stockholders explains a significant portion of the spread. Howe \& Lee (2006) focused on the long-term performance of common stocks and of preferred stock issuers. Based on their research, they reached the conclusion that a significant abnormal underperformance is present only for 1 year after the issue. From the long-term point of view, a consistently significant abnormal performance was not confirmed. This result contrasts with the substantial underperformance of common equity and debt issuers during the 3- or 5-year period post-issue. The better 
long-run performance of preferred issuers relative to common equity and debt issuers is driven primarily by the motivation of financial firms to issue preferred stock to satisfy the regulatory requirements of capital adequacy. The results of other authors differ, therefore, from the results obtained in this paper. It was discovered that currently the marketed preferred stocks in Europe do not show such qualities as are commonly stated. In many cases, they even face a comparable risk as do common stocks. Arcot (2006) presented partially different research and developed a theory of a participating convertible preferred share (PCP) which is usually used to set risk capital. The results show that the qualities of the PCP shares participation and convertibility can be used to decrease the information asymmetry between the enterprise and the potential investors at the time of the output. The function of PCP convertibility helps to reduce the issue of insufficient business effort.

\section{CONCLUSION}

The aim of this article was to analyse risk (measured by beta coefficients) and price volatility among common and preferred stocks and bonds in Europe.

Our analysis confirmed the higher risk for common stocks (beta coefficient mean 0.76) compared to preferred stocks (beta coefficient mean 0.52). However, it no longer applies that the beta coefficient of common stocks is always higher than that of preferred stocks issued by the same company, as has been claimed historically. In 39\% cases, the beta of preferred stocks was higher than the common stock beta. If a difference of up 10\% is considered as negligible, preferred stocks had similar, or higher beta coefficient than the corresponding common stocks (of the same company) in $53 \%$ of cases. In $33 \%$ of cases, the difference is only $\pm 10 \%$. This means preferred stocks should not be automatically considered as less risky than the common shares of the same issuer, at least in Europe. This finding is also supported by an analysis based on volatility of prices (coefficient of variation of prices for common stocks was 0.37 , for preferred stocks 0.30 and for bonds 0.21 ).

On the contrary, the highest volatility was shown for common stocks, and the lowest volatility for bonds, with preferred stocks ranging in the middle, a finding which supports the structuring among them generally described in previous literature.

Preferred stocks paid out dividends in $63-73 \%$ cases in our sample. Nevertheless, no company paid fixed dividends between 2010-2015 (only one paid fixed dividends between 2011-2015). A stable or growing dividend was observed in $20 \%$ of cases in the period $2010-2015$, while no dividends in a certain year or declines in dividends were observed for the rest of the suitable data sample. Between 2010-2015, only 13-45\% preferred stock dividends were fixed between 2 subsequent years. This leads to our conclusion that today preferred stocks in Europe usually bring no fixed dividends.

As another result, our research also showed a preferred stock market price development and common stock market price development correlation coefficient equal to 0.68. From this, we understand that it cannot be stated they are independent to each other overall. Moreover, there is no statistically significant difference between the price development patterns for common stocks, preferred stocks and bonds (paired t-test statistically insignificant).

Our findings support the proposition that preferred stocks do not differ greatly from common stocks, as has been observed historically. Meanwhile, key properties of actual preferred stocks in Europe differ from how preferred stocks are treated in theory (they do not predominantly bear fixed dividends). 
We have identified some topics for future research: Testing to determine whether the these results are homogenous for all the main countries for which pairs of preferred and common stocks have been observed (Russia, Germany, Italy and Sweden). If not, the fundamental reasons should be analysed. A deeper insight into the capital structure of the issuers of preferred and common stocks used in our data sample and its comparison with the capital structures of their peers could bring new information on the rationality of the issuance of preferred stocks in Europe. An analysis of the relationship between dividend stability / policy and differences of common and preferred stock beta coefficients could also extend our findings. A comparison of unlevered common share betas for companies who issue preferred stocks vs those who do not could also bring a new perspective on the role of preferred stocks in the corporate financing. A comparison between the U.S. and European markets could also bring further conclusions relevant for the practical use of capital structure, including preferred stocks in corporate finance. Also, a comprehensive valuation model for preferred stocks should be designed, since valuation procedures typically use common stock beta coefficients derived from similar (peer) companies for non-traded companies, which according to our findings is not appropriate.

\section{Acknowledgements}

This paper is an output of a research project of the Faculty of Finance and Accounting of the University of Economics, Prague that is being implemented as part of institutional support VŠE IP100040 and a research project of the Faculty of Finance and Accounting of the University of Economics, Prague implemented as part of institutional support VŠE IG 104029.

\section{References}

1. Abadi, R., \& Florinda, S. (2019). Common Risk Factors in Stock Returns in the MENA Region. Asian Journal of Business and accounting, 12 (2), 29-60. https://doi.org/10.22452/ajba.vol 12 no2.2

2. Angeline, N., \& Ariff, M. (2019). Does credit rating revision affect the price of a special class of common stock? Borsa Istanbul review. 19 (1), 44-55. https://doi.org/10.1016/j.bir.2019.02.004

3. Arcot, S. (2014). Participating convertible preferred stock in venture capital exits. Journal of business venturing, 29 (1), 72-87. https://doi.org/10.1016/j.jbusvent.2013.06.001

4. Beaupain, R., \& Durré, A. (2016). Excess liquidity and the money market in the euro area. Journal of Macroeconomics, 47 (A), 33-44. https://doi.org/10.1016/j.jmacro.2015.09.001

5. Birger, J. (2008). Be Like Buffett? The Case for Preferred Stock. Fortune. 158 (8), 36-36.

6. Boudry, W. I., deRoos, J. A., \& Ukhov, A. D. (2020). Diversification Benefits of REIT Preferred and Common Stock: New Evidence from a Utility-based Framework. Real Estate Economics, 48 (1), 240-293. https://doi.org/10.1111/1540-6229.12166

7. Bratton, W., \& Wachter, M. L. (2013). A theory of preferred stock. Journal of economics. 61 (7), 1815-1906. http://dx.doi.org/10.2139/ssrn.2214015

8. Brealey, R. A., Myers, S. C., \& Allen, F. (2006). Principles of corporate finance. New York: McGraw-Hill/Irwin, 8th ed.

9. Burne, K. (2013). Preferred Shares Find Favor among Banks. Wall Street Journal. https:// www.wsj.com/articles/SB10001424127887324582004578458982944311840

10. Chang, S., \& Puthenpurackal, J.(2014). Repurchases of convertible preferred stock and shareholder wealth. Journal of business Research, 67 (4), 623-630. https://doi.org/10.1016/j. jbusres.2013.02.042 
11. Choi, P. M. S., \& Choi, J. H. (2018). Is individual trading priced in stocks? Journal of Interantional and Money Finance, 85, 76-92. https://doi.org/10.1016/j.jimonfin.2018.03.004

12. Damodaran, A. (2012). Investment Valuation. New York: John Wiley \& Sons.

13. Ferrer, R., Bolós, V. J., \& Benítez, R. (2016). Interest rate changes and stock returns: A European multi-country study with wavelets. International Review of Economics \& Finance, 44, 1-12. https://doi.org/10.1016/j.iref.2016.03.001

14. Fibírová, J., \& Petera, P. (2013). Profit-Sharing - A Tool for Improving Productivity, Profitability and Competitiveness of Firms? Journal of Competitiveness, 5 (4), 3-25. https://doi. org/10.7441/joc.2013.04.01

15. Han, B. (2010). Preferred Stock Price and Trade Liquidity. Korean Journal of Business Administration, 23 (1), 1-10.

16. Hašková, S., Šuleř, P., Machová, V., \& Krulický, T. (2019). Determining the price of the business share of a business in a group. Ad Alta: Journal of interdisciplinary research, 9 (2), 60-70. https://doi.org/10.33543/0902

17. Horák, J., \& Krulický, T. (2019). Comparison of exponential time series alignment and time series alignment using artificial neural networks by example of prediction of future development of stock prices of a specific company. In Horák, J. SHS Web of Conferences: Innovative Economic Symposium 2018 - Milestones and Trends of World Economy (IES2018).

18. Howe, J. S. \& Lee, H. (2006). The long-run stock performance of preferred stock issuers. Review of Financial Economics, 15 (3), 237-250. https://doi.org/10.1016/j.rfe.2005.08.002

19. Ivanov, I., Kabaivanov, S., \& Bogdanova, B. (2016). Stock market recovery from the 2008 financial crisis: The differences across Europe. Research in International Business and Finance, 37, 360-374. https://doi.org/10.1016/j.ribaf.2016.01.006

20. Kallberg, J. L., Crocker H., \& Villupuram, S. (2013). Preferred stock: Some insights into capital structure. Journal of Corporate Finance, 21 (C), 77-86. https://doi.org/10.1016/j. jcorpfin.2013.01.005

21. La Porta, R., Lopez-de-Silanes, F., Shleifer, A., \& Vishny, R. (2002). Investor protection and corporate valuation. The Journal of Finance, 57 (3), 1147-1170. https://doi.org/10.1111/15406261.00457

22. Lewis, C. M. \& Verwijmeren, P. (2011). Convertible security design and contract innovation. Journal of Corporate Finance, 17 (4), 809-831. https://doi.org/10.1016/j.jcorpfin.2011.03.001

23. Li, G., McCann, C., \& O’Neal, E. (2010). The Risks of Preferred Stock Portfolios. SLCG Working Paper. Securities Litigation \& Consulting Group. http://www.slcg.com/pdf/ workingpapers/Preferred $\% 20$ Stock $\% 20$ Paper.pdf

24. Loviscek, A. L. (2017). Should Preferred Stock Funds Be Included in Mutual Fund Portfolios? The Journal of Wealth Management, 20 (1), 83-96. https://doi.org/10.3905/jwm.2017.20.1.083

25. Majluf, N. S., \& Myers S. C. (1984). Corporate financing and investment decisions when firms have information that investors do not have. The Journal of Financial Economics, 13 (2), 187-9221. 
26. Milonas, N. T. (2000). Similarly Traded Securities: Greek Common vs. Preferred Stock. European Financial Management, 6 (3), 343-366. http://dx.doi.org/10.1111/1468-036X.00128

27. Muravyev, A. (2009). Dual Class Stock in Russia: Explaining a Pricing Anomaly. Emerging Markets Finance and Trade, 45 (2), 21-43. https://doi.org/10.2753/REE1540-496X450202

28. Myers, S. C. (2001). Capital Structure. The Journal of Economic Perspectives, 15 (2), 81-102.

29. Prohaska, Z., Uroda, I., Pesa A.R. (2017). Valuation of Common Stocks Using the Dividend Valuation Approach and Excel. 40th International Convention on Information and Communication Technology, Electronics and Microelectronics (MIPRO).

30. Ravid, S. A., Venezia, I., Ofer, A., Pons, V., \& Zuta, S. (2007). When are preferred shares preferred? Theory and empirical evidence, 3 (3), 198-237. https://doi.org/10.1016/j.jfs.2007.06.003

31. Teplova, T. V., \& Shabalin, P. G. (2017). Preferred Stocks as Instrument for Sustainable Development: Valuation Aspects. Vision 2020: Sustainable Economic Development, Innovation Management, and Global Growth, volsi-ix, 2017, 1728-1737.

32. Vrbka, J., \& Rowland, Z. (2017). Stock price development forecasting using neural networks. In Váchal, Jan; Vochozka, Marek; Horák, Jakub. SHS Web of Conferences - Innovative Economic Symposium 2017: Strategic Partnership in International Trade. 1. ed. Les Ulis, France: EDP Sciences, 8.

33. Wang, L. (2019). Stock Market Valuation, Foreign Investment, and Cross-Country Arbitrage. Global Finance Journal, 40 (C), 74-84. https://doi.org/10.1016/j.gfj.2018.01.004

34. Wise, R. M. (2003). Closely Held Preferred Stock: A Review of the Common Value-Drivers. Business Valuation Review, 22 (3), 149-154. https://doi.org/10.5791/0882-2875-22.3.149

\section{Contact information}

Ing. Tomas Brabenec, Ph.D., LL.M.

University of Economics, Prague

Faculty of Finance and Accounting

Department (Institute) of Corporate Finance

Czech Republic

E-mail:tomas.brabenec@vse.cr.

ORCID: 0000-0001-6348-2252

Ing. Frantisek Poborsky, Ph.D.

University of Economics, Prague

Faculty of Finance and Accounting

Department (Institute) of Corporate Finance

Czech Republic

E-mail:frantisek.poborsky@vse.cz.

ORCID: 0000-0001-5736-5500
Prof. Dr. Sean Patrick Saßmannshausen

Ostbayerische Technische Hochschule Regensburg

Germany

E-mail:sean.sassmannshausen@oth-regensburg.de ORCID: 0000-0001-8265-2413 